\title{
Does economic globalization affect government spending? A meta-analysis
}

\author{
Philipp Heimberger ${ }^{1,2}$ (D)
}

Received: 13 December 2018 / Accepted: 11 February 2020 / Published online: 17 February 2020

(c) The Author(s) 2020

\begin{abstract}
Despite extensive econometric testing, the research literature has been unable to draw firm conclusions regarding the effect of economic globalization on government spending. This paper explores various dimensions of the wide variation in existing estimates of the globalization-spending relationship. By applying meta-analysis and meta-regression methods to a unique data set consisting of 1182 observations from 79 peer-reviewed articles, we find that the evidence rejects theoretical views predicting strong unidirectional effects of economic globalization on government spending. Once we account for publication selection bias, no evidence of a non-zero average empirical effect is found. More importantly, however, the type of government spending matters: while the results are consistent with the view that economic globalization exerts small-to-moderate downward pressure on government spending for social protection and welfare, other spending components are affected less significantly. The meta-regression analysis shows further that several factors influence the globalization-spending estimates reported in the literature, including the choice of the economic globalization indicator, details of the econometric specifications, and publication characteristics.
\end{abstract}

Keywords Globalization · Trade openness · Financial openness · Government spending · Meta-analysis

JEL Classification $\mathrm{H} 7 \cdot \mathrm{H} 87 \cdot \mathrm{C} 23$

Electronic supplementary material The online version of this article (https://doi.org/10.1007/s1112 7-020-00784-8) contains supplementary material, which is available to authorized users.

Philipp Heimberger

heimberger@wiiw.ac.at

1 Vienna Institute for International Economic Studies, Rahlgasse 3, 1060 Vienna, Austria

2 Institute for Comprehensive Analysis of the Economy, Johannes Kepler University Linz, Linz, Austria 


\section{Introduction}

Over recent decades, the relationship between globalization and the nation state has become one of the most pressing social science controversies. Despite a wave of academic research, the exact nature of that relationship remains unclear. How does the growing market integration of international trade and finance affect government spending? To answer that question, scholars have developed and tested various theories, but controversy continues across the disciplines of political science, sociology and economics (e.g., Garrett 1995; Cusack 1997; Rodrik 1998; Bretschger and Hettich 2002; Rodden 2003; Adam and Kammas 2007; Dreher et al. 2008b; Epifani and Gancia 2009; Kwon and Pontusson 2010; Leibrecht et al. 2011; Wu and Lin 2012; Marshall and Fisher 2015). On a theoretical level, most of the extant literature addressing the impact of globalization on government spending is framed as a debate on whether the 'efficiency' hypothesis or the 'compensation' hypothesis holds.

The 'efficiency' hypothesis states that globalization puts pressure on governments to introduce tax cuts, as lower tax rates are supposed to prevent mobile capital from leaving a country. As financial market actors threaten to punish deficit spending by demanding higher interest rates, international tax competition eventually leads to expenditure retrenchment, with particular downward pressure placed on social protection and welfare spending (e.g., Garrett 1998a; Scharpf and Schmidt 2000; Adam et al. 2013). The 'compensation' hypothesis generates the opposite prediction: globalization causes an expansion of government spending and strengthening of the nation state's social safety net because voters push policymakers to compensate them for greater external risk and its social consequences (e.g., Cameron 1978). By voicing skepticism about predictions that globalization has a strong and unidirectional impact on government spending (in one direction or the other), it also has been argued that other factors - such as partisan politics, democracy and the state of the domestic economy - are much more salient than globalization when it comes to explaining (changes in) government spending, although globalization may still have small effects (e.g., Kittel and Winner 2005). More importantly, theory does not establish an unambiguous relationship between globalization and different types of government spending. In addition, the existing literature has not been able to produce econometric evidence to resolve conflicting theoretical arguments: prominent empirical evidence is consistent with the 'efficiency' hypothesis (e.g., Busemeyer 2009), the 'compensation' hypothesis (e.g., Rodrik 1998; Epifani and Gancia 2009) and with the view that globalization is not very important when it comes to explaining government spending (e.g., Steinmo 2002; Brady et al. 2005). Available econometric findings are divided; while positive and negative globalization-spending effects are reported, several studies cannot reject the hypothesis that the effect is indistinguishable from zero. Against that background, valid generalizations are difficult to draw based on traditional literature reviews of the available globalization-spending evidence (e.g., Stanley 2001).

This article contributes to the literature by presenting the first quantitative literature review of the effect of globalization on government spending using meta-analysis and meta-regression techniques (e.g., Stanley and Doucouliagos 2012; Schmidt and Hunter 2014), allowing us to conduct formal hypothesis tests and to draw statistical inferences. As it is well known that differences in econometric specifications and in the data relied on can have sizeable impacts on empirical estimates, this paper sets out to make sense of the substantial variation in estimates on the relationship between globalization and government spending. We tackle two main research questions. First, what does the existing evidence 
tell us about the effect of globalization on government spending? Meta-analysis in combination with formal tests of publication selection bias allow us to provide answers to the first research question by means of a comprehensive survey and quantitative analysis of the relevant econometric estimates on the globalization-spending relationship (see Sects. 3 and 4). Second, what factors explain the present heterogeneity in reported results on the globalization-spending nexus? We use meta-regressions to address the second research question by exploring the impacts of data structure, econometric specification details and publication characteristics on the reported globalization-spending estimates (see Sect. 5).

\section{The theoretical background to the debate on globalization and government spending}

This section focuses on two main issues for a quantitative literature review of the globalization-spending relationship. First, how can globalization be defined and how does the literature measure that concept? Second, what are the most important theoretical arguments about how globalization may influence government spending?

\subsection{How to define and measure globalization?}

Definitions and images of globalization vary widely. In this paper, we focus on "economic globalization", which is a much narrower concept than globalization per se, as the latter is a multifaceted concept consisting of different aspects of the economic, political and social sphere (e.g., Dreher et al. 2008a; Scholte 2008). Clark (2000, p. 86) prominently defines globalization as "the process of creating networks of connections among actors at multicontinental distances, mediated through a variety of flows including people, information and ideas, capital, and goods". Various students of the globalization-spending relationship have developed a large number of indices to operationalize this multifaceted process of globalization. Herein, we restrict the analysis to the economic dimension capturing trade and financial openness. Brady et al. (2005, p. 922) conceptualize economic globalization as "the intensification of international economic exchange and the label for the contemporary era of international economic integration. Thus, [economic] globalization involves the current economic environment shaping welfare states and the heightening of concrete economic exchanges between countries."

We follow accepted typologies of available economic globalization indicators, which distinguish between trade globalization, financial globalization and overall economic globalization, such that measures of the latter combine the trade and financial dimension (e.g., Squalli and Wilson 2011; Gräbner et al. 2018; Gygli et al. 2019). By far the most prominent trade globalization indicator is trade's share in GDP (measured as the sum of imports and exports as percentage of GDP). In the dimension of financial globalization, researchers have adopted measures such as foreign direct investment (FDI) flows and indices for capital account liberalization. Furthermore, the globalization index of the Swiss Economic Institute (KOF) has emerged as the most popular overall economic globalization measure (Dreher 2006; Potrafke 2015). Our meta-data coding regarding the relevant economic globalization indicators follows the typology developed in Gräbner et al. (2018) along the dimensions of trade globalization, financial globalization and overall economic globalization (see the appendix for more details). Although our focus is on "economic globalization", for the sake of simplicity the present paper generally refers to it as "globalization". 


\subsection{Competing hypotheses on how globalization affects government spending}

A general consensus exists that "[w]e can no longer understand politics within countrieswhat we still conventionally call 'domestic' politics-without comprehending the nature of the linkages between national economies and the world economy, and changes in such linkages" (Milner and Keohane 1996, p. 3). In that context, academic researchers have proposed three competing theories. First, globalization may lead to substantial retrenchment in public spending. Second, globalization may cause government expenditures to expand markedly. Third, globalization nevertheless may have small (although not unidirectional) effects on government spending, but domestic factors may be more important determinants of public expenditures.

The first theory-globalization causes spending retrenchment-has been called the 'efficiency' hypothesis. In its simplest version, it stipulates that globalization reduces public expenditures because international competition effectively triggers a 'race for the best location' across nations, which fosters tax competition and leads to expenditure retrenchment as the more complete international integration of financial markets also penalizes deficit spending (e.g., Sinn 1997). The logic for capital mobility is that the greater potential for capital flight across borders has rendered financial market investors the ultimate arbiters of fiscal policymaking, as they effectively can 'punish' governments by selling-off government bonds (e.g., Streeck 2014). Hence, the simple version of the 'efficiency hypothesis' predicts that governments respond to globalization by introducing substantial cuts in public expenditures.

An extended version of the 'efficiency' hypothesis is more complex in the sense that it makes clear predictions about what kind of government expenditures will be affected negatively by globalization: here, the prediction is that globalization puts particular downward pressure on public expenditures for social protection and welfare, since the welfare state comes under attack owing to concerns that redistributive fiscal policies may hamper international 'competitiveness' (e.g., Alesina and Perotti 1997). While welfare spending is subject to globalization-induced fiscal consolidation pressures, the extended version of the 'efficiency' hypothesis concedes that other components of government spending nevertheless could be expected to respond positively to increasing international market integration; for example, public infrastructure or education spending may increase in response to globalization as governments try to make their locations more attractive to foreign investors, thereby ensuring international competitiveness (e.g., Schulze and Ursprung 1999). As different components of government spending can be expected to respond differently to globalization (in particular: spending on social protection and welfare vs. public infrastructure expenditures), it is not possible to test the extended 'efficiency' hypothesis by looking only at total government spending. Our meta-analysis will, therefore, consider different types of government spending.

The second theory — globalization causes expanding public spending — can be called the 'compensation' hypothesis. It makes the theoretical prediction that more trade and greater financial openness lead to larger public sectors. The argument basically is about political incentives for expansionary spending policies, as citizens demand that policymakers compensate them directly for the increases in external risk and social polarization that are associated with international integration. Integration of international trade and financial markets may increase economic inequality and insecurity. In that context, governments have strong incentives to recompense their citizens. In his seminal paper on the "compensation' hypothesis, Rodrik (1998, p. 1019) argues that "[i]f government spending played a 
risk-mitigating role, we would expect to see this primarily reflected in income transfer programs and in social security and welfare spending." Hence, while the simple version of the 'compensation' hypothesis does not make specific predictions about which types of government spending will be affected by globalization, the extended version states that governments respond to globalization by building stronger safety nets and engaging in additional welfare spending. Both the 'efficiency' as well as the 'compensation' theory assigns special roles to social spending, although their extended versions clearly make opposing predictions regarding the unidirectional impact of globalization on social spending.

The third view is skeptical about theoretical claims that globalization produces strong and unidirectional effects on government spending, as suggested by both the 'efficiency' and the 'compensation' theory. Such skepticism rests mostly on theoretical arguments according to which other factors are more important determinants of government spending than globalization. A comprehensive survey would go beyond the scope of the present paper, but the third view generally stresses the importance of each nation's own history in terms of institutions and culture (e.g., Navarro et al. 2004) as well as of the structure of the welfare state and the political system (e.g., Cusack 1997; Kim and Zurlo 2009). Empirical studies zooming in on the domestic determinants of government spending focus on explanatory variables such as partisan politics and democracy (e.g., Garrett 1998b; Kittel and Obinger 2003), fiscal decentralization (e.g., Rodden 2003; Ha 2008), the changing age structure of the population (e.g., Razin et al. 2002; Shelton 2008) and the state of the domestic economy (e.g., Stephens et al. 1999; Kittel and Winner 2005). Nevertheless, it is important to note that recognizing domestic influences on public spending does not necessarily imply that globalization has no effect at all: the impact of globalization on various components of government expenditures still may be non-zero, but smaller than suggested by either the 'efficiency' or the 'compensation' hypothesis and, moreover, not unidirectional across countries.

Numerous contributions to the literature have tried to test the foregoing competing theories of how globalization affects government spending-with inconclusive results (e.g., Rodrik 1998; Kittel and Obinger 2003; Brady et al. 2005; Busemeyer 2009; Epifani and Gancia 2009; Marshall and Fisher 2015; Chuaire et al. 2017). Thus far, academic research has not made an effort to synthesize and explore the published estimates of the globalization-spending relationship; the present article closes that gap in the literature by applying meta-analysis and meta-regression tools.

\section{Constructing the meta-study dataset on the globalization-spending relationship}

Based on the widely used KOF globalization index (on the index's construction, see Gygli et al. 2019), Panel A of Fig. 1 shows for a sample of advanced countries that economic globalization expanded markedly from the 1980s to the mid-2000s, but has stagnated over the past 10 years. Given the substantial overall growth in economic globalization since the 1980 s, research interest in studying the effects on the public sector also has risen. Panel B of Fig. 1 plots the average relationship between the KOF economic globalization index and total government spending over the 1980-2016 period. The plot does not show much of a systematic relationship: the economic globalization index explains only about $3 \%$ of the variation in total government spending. However, if one were to conduct a detailed analysis of how globalization affects government spending, the picture could change; several 
Fig. 1 Economic globalization and government spending in advanced countries. Data for the KOF economic globalization index were obtained from Gygli et al. (2019). Data on total government spending were downloaded from the World Bank. The economic globalization data in Panel A depict an unweighted average of the 27 advanced countries that were also included in panel B
Panel A. Economic globalization (1980-2016)

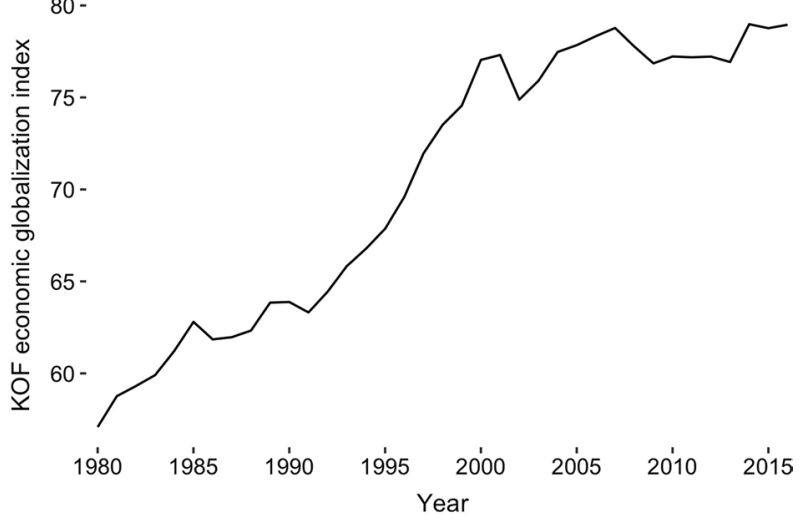

Panel B. Economic globalization and total governmen

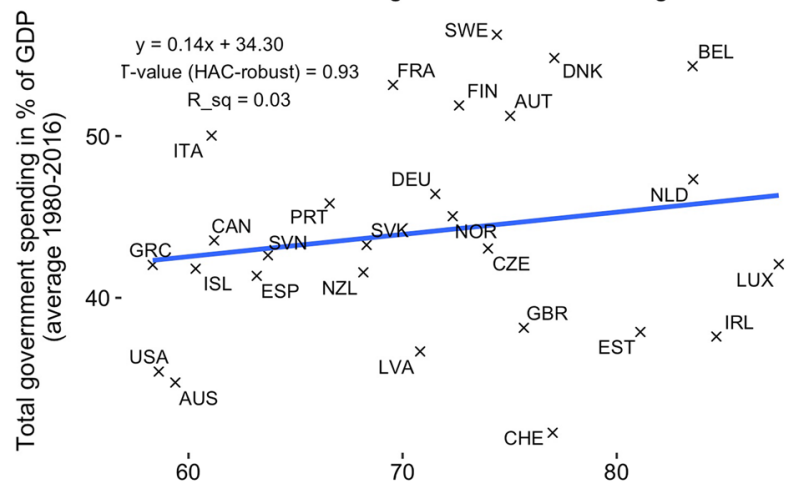

KOF economic globalization index (average 1980-2016)

aspects of the relationship need to be considered: the choice of the globalization measure (overall economic globalization as in Fig. 1 or sub-indicators for trade and financial globalization?), the composition of government spending (total government spending or different sub-components of it?), the time dimension of the data, the composition of the country sample (include developing countries?), the structure of the data (cross-sectional or panel?), the functional form of the model (in levels or first differences?), the estimator (OLS with fixed effects or GMM?), and so on.

As the following meta-analysis will show, a large number of studies have generated independent estimates of the relationship between economic globalization and government spending. However, no single study is able to provide a valid basis for drawing conclusions about what we know about that relationship: reliance on "best studies" or qualitative literature reviews does not resolve the problem of conflicting research findings (Schmidt and Hunter 2014, p. 19). The advantages of meta-analysis are well known, and this paper utilizes them: we integrate the findings across the empirical literature on the globalizationspending relationship (see Sect. 3) and correct for the distorting effects of several data artifacts that may produce the illusion of conflicting findings. In doing so, we identify the extent to which the particular choice of methods, empirical designs and data structures affect the results reported in the globalization-spending literature. We thereby contribute 
to explaining wide variation in existing estimates. Like all other statistical tools, however, meta-analysis has its own downsides and weaknesses (e.g., Stanley 2001, p. 146). This paper addresses potential problems with our use of meta-analysis in the following ways. First, disagreement exists over which study characteristics to include in a meta-analysis of the globalization-spending relationship. The issue of what study characteristics are important, however, can be examined statistically (see Sect. 5). Second, a problem arises when meta-analysis weights relevant reported estimates equally, because it then risks overweighting the "lower quality" results. That point, however, can be addressed by using a properly weighted estimator (see Sect. 5). Third, a problem of publication selection bias arises, as statistically significant effects could be more likely to be published, which would distort the findings. We can address that issue, however, by accounting for potential publication selectivity (see Sect. 4). Fourth, the criteria adopted for including and excluding studies may be opaque. Our approach, therefore, is to be transparent about the criteria for inclusion.

\subsection{Search strategy and criteria for inclusion}

The systematic search and review of the literature for this paper began by tracking down all relevant journal articles addressing the relationship between globalization and government spending. By doing so, we included papers from a variety of academic fields, most prominently political science, sociology and economics. To search for papers, we first accessed (1) Google Scholar, (2) the EconLit database and (3) the Scopus database. We included the following keywords in the search process: "globalization + government spending"; "openness + government spending"1 (we also substituted "government spending" by "public expenditures" and "government expenditures", respectively). Furthermore, we followed up on the references cited in empirical studies and reviews of the relevant literature by screening article reference lists. The criteria for including existing studies in the meta-analysis sample are as follows:

(a) Government spending as the dependent variable and globalization as explanatory variable As a condition for being included in our dataset, articles use a measure of government spending as the dependent variable and at least one measure of globalization as an explanatory variable. Studies had to report estimates of some variant of the following generic econometric model (note that we ignore subscripts for the purpose of simplification):

$$
\text { GOVSPEND }=\alpha+\beta_{1} \text { EGLOBAL }+\beta_{x} Z_{x}+\varepsilon,
$$

where GOVSPEND as the dependent variable is a measure of government spending, EGLOBAL is a measure of economic globalization, ${ }^{2} \mathrm{Z}$ is a vector of other explanatory variables, and $\varepsilon$ is the error term. For example, articles adopting a measure of tax rates or tax revenues as the dependent variable (e.g., Cameron 1978; Swank 1998;

\footnotetext{
1 We also used the British English version ("Globalisation") as a keyword in our database search.

${ }^{2}$ Note that we only coded estimates that adopted government spending as the dependent variable and an economic globalization variable as regressor. Beyond that, the studies included in the meta-study dataset typically do not consider the issue of reverse causality, i.e., that the level of government spending could drive a country's exposure to globalization.
} 
Adam et al. 2013) as well those using globalization measures that do not consider the dimension of economic globalization exclusively but in combination with political or social dimensions (e.g., Potrafke 2009) had to be excluded.

(b) Reported econometric estimates Only those empirical studies that presented regression results were considered. That restriction excluded numerous papers that reported descriptive statistics or qualitative reviews only.

(c) Published in peer-reviewed journals We included only the empirical estimates that were published in peer-reviewed English-language journals prior to October $2018 .^{3}$ We excluded other works on the globalization-spending nexus (e.g., working papers and book chapters). First, peer-reviewed journal publications can be considered to have passed a certain "quality" check by referees and editors. Second, it is difficult to track down all potentially relevant book chapters and other non-peer-reviewed documents that touch on the globalization-spending relationship. Therefore, the restriction to peerreviewed journal articles contributed to ensuring that the coding process remained transparent and manageable.

(d) Offered relevant statistics In order to be included in our sample, an article had to fulfill certain reporting standards: the requirement was that the paper offered statistics (e.g., correlation coefficients and standard errors or t-statistics) from which standardized measures of the impact of globalization on spending could be computed (see Sect. 3.2).

Seventy-nine journal articles fulfilled the four criteria, yielding a total of 1182 estimates for the meta-study dataset. In the accompanying appendix, we present a table listing all of the 79 included studies. The estimates compiled from those studies comprise our total population of the relationship between globalization and government spending.

\subsection{The globalization-spending nexus: comparable effect sizes and their standard errors}

Not all of the relevant coefficients found in the globalization-spending literature are directly comparable, as the variables entered into the regressions are measured on different scales. For example, if some estimates are based on log-transformations of the underlying variable, but other estimates are not based on such a transformation, the size of the coefficients is difficult to compare. To illustrate the magnitude of the effect of globalization on government spending, we therefore need to make all estimates comparable. In the context of the present paper, partial correlation coefficients measure the strength and direction of the impact of globalization on government spending, while holding other factors constant. The two main advantages of the partial correlation coefficient are: first, it can meaningfully be compared across articles because it is unit free and bounded between -1 and 1 . Second, it can be calculated for a much larger set of estimates than other effect size measures. Formally, the partial correlation coefficient is given by:

$$
r=\frac{t}{\sqrt{t^{2}+d f}},
$$

\footnotetext{
${ }^{3}$ Note that we also included papers that (up to September 2018) were accepted for peer-reviewed publication, but not yet assigned to an issue of the respective journal.
} 
where $t$ is Student's $t$-statistic associated with the relevant regression coefficient and $d f$ denotes the degrees of freedom for that $t$-statistic (Stanley and Doucouliagos 2012, p. 25). The standard error of the partial correlation coefficient (ser) is given by $\operatorname{ser}=\sqrt{\frac{1-r^{2}}{d f}}$, where $r$ again is the partial correlation coefficient and $d f$ denotes degrees of freedom. Summary results for the partial correlations and associated confidence intervals (e.g., Schmidt and Hunter 2014) are available in the accompanying appendix.

\section{Is the globalization-spending literature characterized by publication selection bias?}

Publication selection bias could be a severe problem for economic interpretations and statistical inferences (e.g., DeLong and Lang 1992). Indeed, it has been argued that the empirical literature on the globalization-spending nexus is characterized by a certain asymmetry in favor of the compensation argument with the consequence that "most of the more recent innovative theoretical work has concentrated on the 'compensation' argument by alluding to the need to provide a better understanding of the political underpinning of the compensation logic" (Busemeyer 2009, p. 457). If that were true, it may imply a publication selection bias in favor of results that support the 'compensation' hypothesis, according to which globalization increases government spending to offset the risks associated with international market integration. In this section, we test formally whether such a concern is indeed valid.

Publication selection refers to a process in which results are chosen for their statistical significance (e.g., Brodeur et al. 2016; Andrews and Kasy 2019). The tendency of journal editors to publish only those results that reveal statistical significance, the researchers' willingness to take the presence of statistically significant effects based on accepted theory and the general predisposition for treating statistically significant results more favorably than "insignificant" evidence may lead to a distorted picture of the underlying empirical relationship.

If publication bias is not an issue, the partial correlation coefficient and its standard error will not show any systematic relationship. However, if published results are biased, we will find a statistically significant relationship (Egger et al. 1997). ${ }^{4}$ It has been argued that the "simplest and most commonly used method to detect publication selection is an informal examination of a funnel plot" (Sutton et al. 2000, p. 1574). Here, the funnel plot represents a scatter diagram consisting of all econometric estimates of the globalizationspending relationship in our sample and the precision of those estimates, where precision is calculated as the inverse of the standard errors of the partial correlation coefficients (see Fig. 2). The most precise estimates of the globalization-spending nexus are shown at the top; they are the least affected by publication selection bias because their high precision makes it rather unlikely that they are statistically insignificant. In the absence of publication bias, the funnel plot should be symmetric-implying that the most precise estimates are close to the true effect, while low-precision estimates are characterized by large standard errors. As a consequence, if publication selection bias is absent, the scatter plot should

\footnotetext{
${ }^{4}$ In our case, the significant relationship between partial correlations and standard errors would need to be positive if there is publication selectivity in favor of the "compensation" hypothesis, and negative to be consistent with selectivity favoring the "efficiency" hypothesis.
} 
Fig. 2 The distribution of globalization-spending estimates. The figure plots estimates of the partial correlations against the inverse of the corresponding standard error

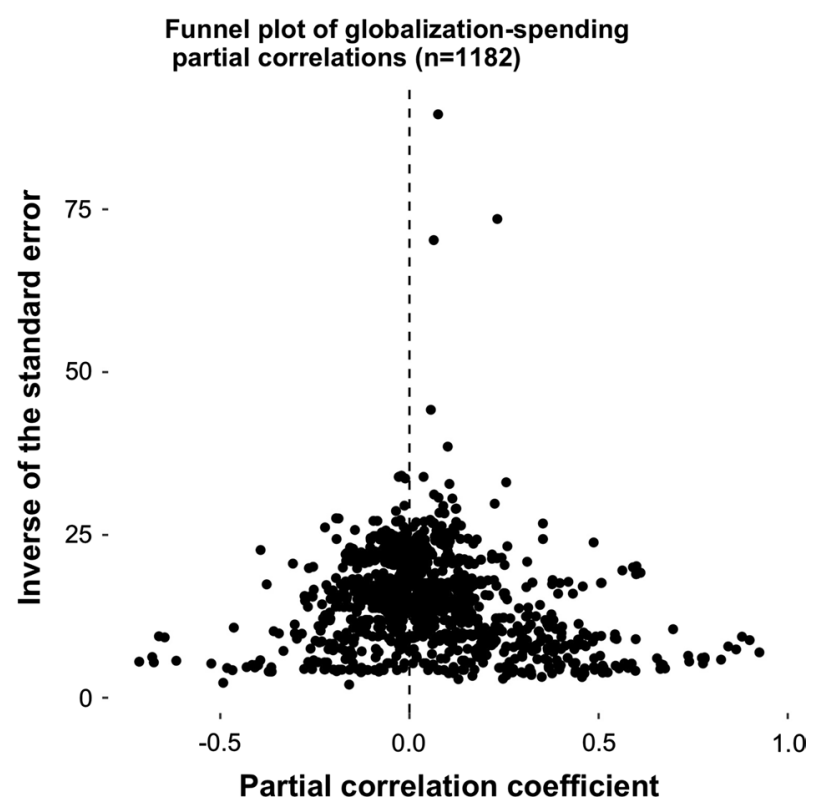

be shaped like an inverted "funnel" (Sutton et al. 2000). The visual inspection of Fig. 2 suggests that the reported estimates are characterized by large variation ${ }^{5}$ : negative, positive and close-to-zero estimates are reported. However, the right portion of the funnel seems to be "heavier" than the left portion, which could be an indication of publication selection bias.

We continue by applying the funnel-asymmetry precision-effect test (FAT PET), which allows us to formally test the presence of publication selection bias. We estimate the following model:

$$
r_{i j}=\beta_{0}+\beta_{1} \mathrm{SE}_{i j}+\varepsilon_{i j},
$$

where $r_{i j}$ is the estimated partial correlation $i$ from study $j, \mathrm{SE}_{i j}$ is its standard error and $\varepsilon_{i j}$ is the random sampling error. In Eq. (3), the term $\beta_{1} \mathrm{SE}_{i j}$ allows for publication selection bias. The hypothesis test of $\beta_{1}\left(\mathrm{H}_{0}: \beta_{1}=0\right)$ can be called the funnel asymmetry test (FAT). If $\beta_{1}$ equals zero, we find no evidence for publication selection bias (Egger et al. 1997). At the same time, testing the hypothesis that $\beta_{0}$ is zero (referred to as the precision-effect test, or PET) allows us to test whether an empirical effect remains after accounting for potential publication selection bias. The reported empirical estimates, however, come from different datasets with various sources of heteroscedasticity, and they must be expected to have different variances. To address that issue, we estimate Eq. (3) by Weighted Least Squares (WLS) with the inverse of the variances as weights. ${ }^{6}$

\footnotetext{
${ }^{5}$ Additional information on the distribution of the partial correlation coefficients is available in the accompanying appendix.

${ }^{6}$ It has been shown that the inverse of the partial correlation coefficients' variances are the optimal weights (e.g., Cooper and Hedges 1994).
} 
Table 1 FAT-PET results

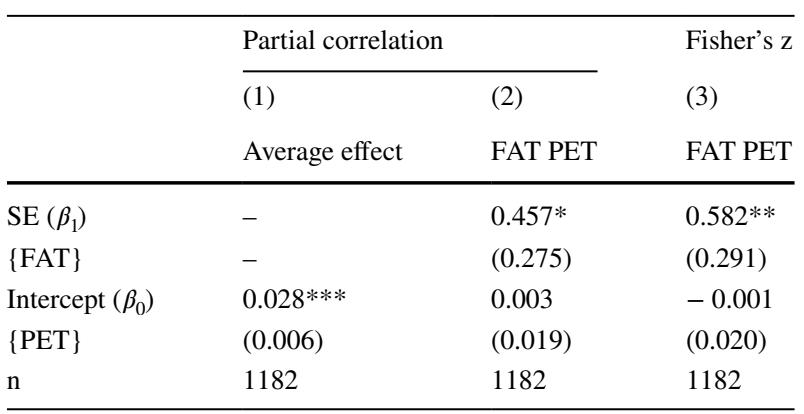

The dependent variable is the partial correlation in columns (1)-(2) and Fisher's z-transformed partial correlation in column (3). Figures in brackets are clustered (heteroskedasticity-robust) standard errors. $\mathrm{n}$ is the number of observations. Column (1) reports results from regressing the partial correlation coefficient on a constant. Estimates reported in column (2) and (3) are based on Eq. (3). All results were obtained by using Weighted Least Squares (weights based on the inverse of the variances). The FAT tests for the presence of publication selection bias. The PET estimates the average effect of economic globalization on government spending corrected for publication selection bias. *, $* *$, *** denote statistical significance at the $10 \%, 5 \%$ and $1 \%$ level, respectively

We start by reporting the precision-weighted average, obtained from regressing the partial correlation coefficients on a constant term by applying WLS (see column (1) of Table 1). Without correcting for publication selection bias, evidence of a positive and statistically significant impact of globalization on government spending emerges. Note, however, that according to the guidelines in Doucouliagos (2011), which suggest that a partial correlation below 0.07 can be considered to be small, the (precision-weighted) average partial correlation estimate reported in column (1) is very small. Column (2) of Table 1 then accounts for potential publication selection bias. It reports the results based on Eq. (3). The FAT results in column (2) indeed provide evidence of publication bias: the association between the partial correlations and their standard errors is positive and statistically significant. The PET results in column (2) offer no evidence of a genuine empirical effect once we correct for the upward publication selection bias. A potentially important drawback of using the partial correlation coefficient is that its distribution is not normal when its value is close to -1 or +1 (Stanley and Doucouliagos 2012, p. 25). In our case, though, departure from normality is unlikely to be a problem, since only a few partial correlations are anywhere near the $-1,+1$ bound (see Fig. 2). Nevertheless, we implement the most common solution for that potential problem, which is to use Fisher's $z$-transformation (e.g., Dunn and Clark 1969). As can be seen from column (3) of Table 1, the FAT PET results prove robust when Fisher's $z$-transformation is applied to the partial correlations. ${ }^{7}$

Overall, the FAT results reported in columns (2)-(3) of Table 1 provide evidence that the reported estimates are selected in part for statistical significance in favor of the

\footnotetext{
7 We did not estimate the PESEE (precision-effect estimate with standard error) specification, which would use the variance (instead of the standard error) in Eq. (3). The reason for sticking with the FAT-PET is that when no true effect exists, the model with the standard error is correctly specified and provides a less biased estimate of the precision coefficient (e.g., Stanley and Doucouliagos 2012, p. 66).
} 
'compensation' hypothesis. But does the extent of publication selectivity make a practical difference? To answer that question, we exploit the fact that the FAT coefficient $\beta_{1}$ is a unit-free measurement, which makes it possible to rely on it for assessing the magnitude of publication selection bias. Doucouliagos and Stanley (2013) argue that when the FAT is statistically insignificant or if $\left|\beta_{1}\right|<1$, then selectivity is "little to modest" (Doucouliagos and Stanley 2013, p. 320). In our case, the FAT coefficient is statistically significant, but it is much smaller than one: while some evidence of publication selection bias is found, the bias is small and thus should not make too much of a practical difference in the interpretation of the literature's empirical results. This conclusion is consistent with visual inspection of Fig. 2: although the right portion of the funnel is a bit "heavier" than the left one, the dispersion of the estimates is relatively wide and symmetric, which does not indicate strong publication selectivity.

However, the findings reported thus far are subject to three major limitations. First, the literature review in Sect. 2.1 has established that different dimensions of economic globalization (trade and financial globalization, respectively) might have different impacts on government spending. We have not yet accounted for that important point. Second, the literature review in Sect. 2.2 has shown that, based on theoretical considerations, different components of government spending can be expected to respond differently to globalization (especially spending on social protection vs. public infrastructure). Addressing that aspect of the relationship is essential because the extended versions of the 'efficiency' and 'compensation' hypotheses can be put to thorough test only by accounting for different types of government spending. Third, other sources of heterogeneity (e.g., data characteristics, estimation details and publication characteristics) might explain some of the diversity in the published empirical results. To address those three points, the next section investigates heterogeneity and publication bias simultaneously in a multivariate meta-regression analysis.

\section{What factors explain the heterogeneity in reported globalization-spending estimates?}

What factors contribute to explaining the heterogeneity in the reported empirical results on the globalization-spending relationship? We continue by identifying the likely sources of heterogeneity.

\subsection{The multivariate meta-regression model}

In line with standard techniques for meta-regression analysis (e.g., Stanley and Doucouliagos 2012), we adopt the assumption that the $i$ th estimate of the globalization-spending partial correlation coefficient from study $j$, denoted $r_{\mathrm{ij}}$, is influenced not only by sampling error $\left(\varepsilon_{i j}\right)$, but by a vector of variables $\left(Z_{k i j}\right)$ consisting of characteristics that capture differences in the underlying effect of globalization on government spending. The meta-regression model can thus be written as follows:

$$
r_{i j}=\beta_{0}+\sum \beta_{k} Z_{k i j}+\beta_{1} \mathrm{SE}_{i j}+\varepsilon_{i j}
$$

By estimating Eq. (4), we can account simultaneously for publication selection bias (the standard error SE is still included) and for the factors that might explain excess 
heterogeneity. We estimate Eq. (4) by WLS with the inverse of the variances as optimal weights. Stanley and Doucouliagos (2017) argue that the WLS estimator is preferable to other standard estimators that can be applied in meta-regressions. WLS is preferred since the estimates do not have the same variances and because it is important to assign more weight to those estimates that are more precise. However, we also will conduct robustness checks based on applying different estimators. As most of the studies in our meta-study database report several estimates, we also correct for potential within-study dependence by clustering the standard errors obtained from the meta-regression model at the study-level.

\subsubsection{Measures of the dependent variable (government spending)}

Recall that the dependent variable in the meta-analysis is a measure of public spending (see Eq. 1). We account for differences in the dependent variable by distinguishing estimates that use total government spending, government consumption, public investment, social spending, education spending, health spending and other (unspecified) types of spending (i.e., variables consisting of mixes of spending categories), respectively (see Table 2). By considering differences in the measures of government spending, we are able to test the extended versions of the two competing hypotheses regarding the impact of globalization on public expenditures introduced in Sect. 2.2 ('efficiency' vs. 'compensation').

\subsubsection{Measures of economic globalization}

As explained in Sect. 2.1, numerous indicators have been applied in capturing different aspects of globalization. We follow the typology of economic globalization indicators in Gräbner et al. (2018), distinguishing between trade globalization, financial globalization and overall economic globalization indices; the latter combine both the trade and financial dimensions (see the appendix for more details).

\subsubsection{Data characteristics}

We consider whether a study relies on cross-sectional data rather than panel data. Additionally, Rodrik (2011) suggests something special about the period of 'hyper-globalization' during the 1990s. Including a continuous variable for the mean year in the various published samples is an approach for testing whether the time dimension of the data matters.

\subsubsection{Country composition}

The globalization-spending relationship could be influenced by the underlying country sample (e.g., Rudra 2002). We thus control for whether an estimate is based on advanced countries, developing countries or a mix of the two. To distinguish between the three country groups, we make use of the IMF's (2018) classifications.

\subsubsection{Econometric details}

We test formally whether the functional form of the econometric model makes a difference, as suggested by a number of contributions to the relevant literature (e.g., Garrett 2001; Kittel and Obinger 2003; Kittel and Winner 2005). We distinguish between estimates that specify both the dependent variable and the relevant globalization regressor in levels and 


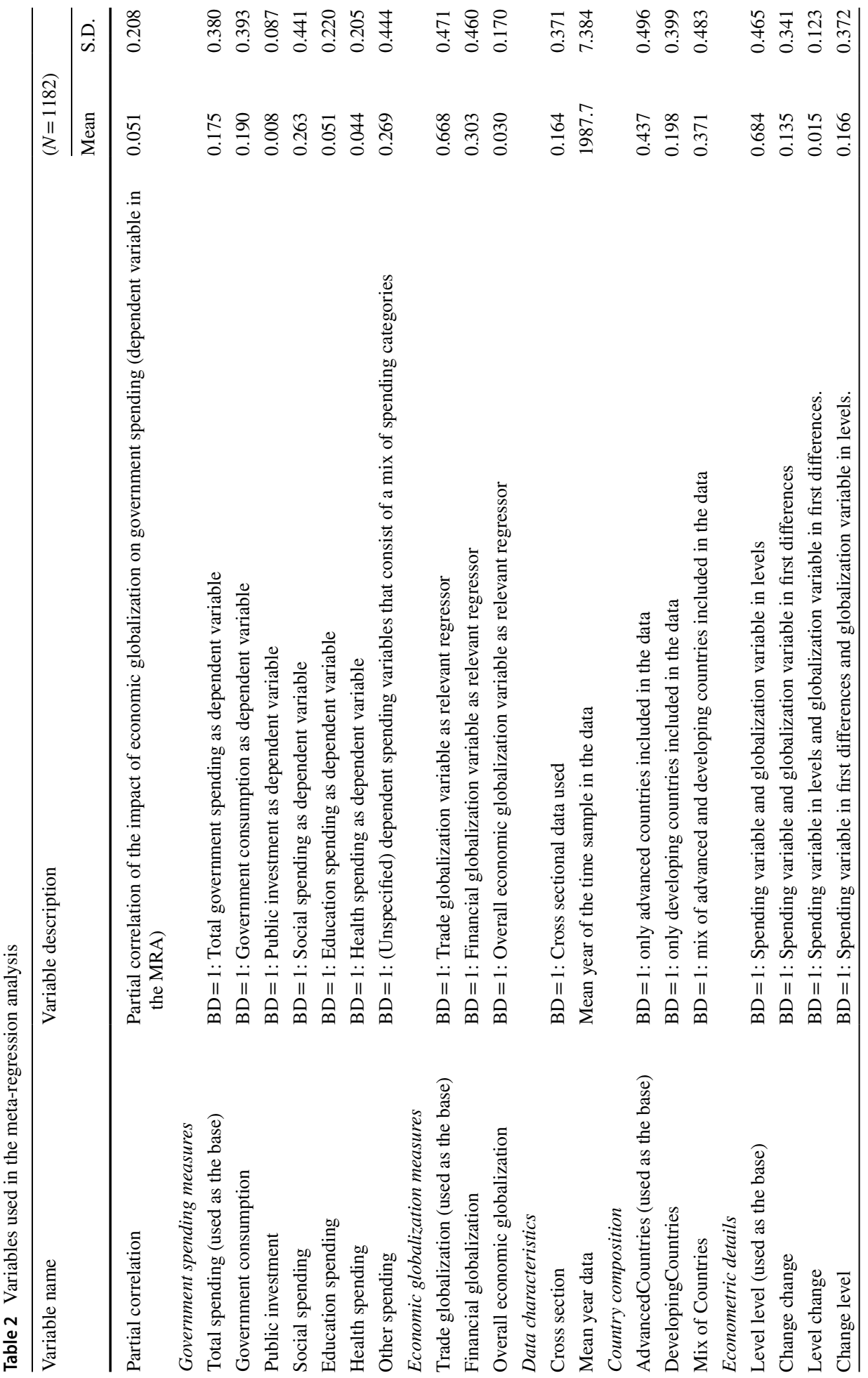




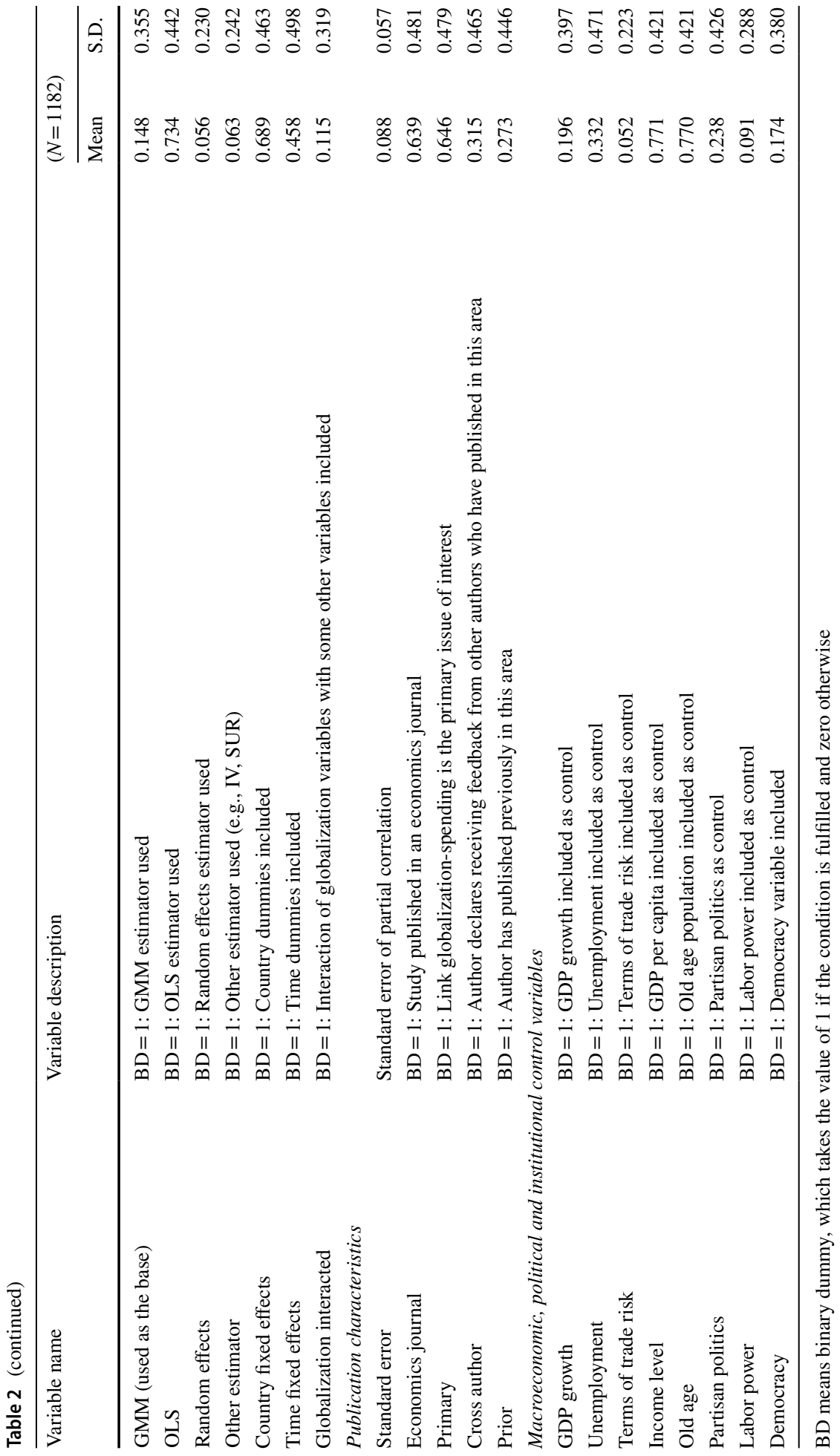


other functional forms of the globalization-spending relation. We identify specifications in first differences on both side of the empirical model (ChangeChange), specifications that regress the level of government spending on first differences in the relevant globalization variables (LevelChange), and specifications that regress first difference in government spending on the level of globalization (ChangeLevel).

We account for differences in the empirical estimators by coding a variable for GMM, OLS, Random Effects and other estimators (such as Instrumental Variables and Seemingly Unrelated Regressions), respectively. We also check whether differences emerge in the reported results when estimates control for unobserved country heterogeneity (CountryFixedEffects) and time-varying shocks affecting all countries (TimeFixedEffects). Furthermore, we consider whether the regression model entered an interaction term between globalization and some other variable.

\subsubsection{Publication characteristics}

We account for various dimensions of the publication process: differences between economics journals and other types of journals, whether a study's primary focus is the globalization-spending relationship as opposed to entering globalization merely as a control variable, and whether the author(s) of a study previously received comments or feedback from other authors who have contributed to the relevant literature. ${ }^{8}$

\subsubsection{Macroeconomic, political and institutional control variables}

Finally, we consider whether the inclusion of potentially relevant control variables has an impact on the reported relationship between globalization and government spending. Several studies account for macroeconomic factors, represented by GDP growth and the unemployment rate, respectively. We also check whether studies control for income levels (proxied by GDP per capita). Some authors have argued that government spending plays an important risk-reducing role, particularly in economies that are exposed to substantial external risks (e.g., Rodrik 1998; Epifani and Gancia 2009); hence, we consider whether the sampled studies control for terms-of-trade risk. An important argument is that demographic change affects government spending, with particular importance for an aging population (e.g., Shelton 2008); we thus check whether it matters whether or not the share of the aged population is accounted for. The political science literature has emphasized that the identities of the parties running the government matter, since their ideological leanings may lead to quite different spending policies, even in the context of globalization (e.g., Cusack 1997; Belke 2000; Kittel and Obinger 2003). We thus also ask whether entering controls for partisan politics affects reported partial correlations. The political science literature likewise highlights the salience of labor's institutional powers in the context of government spending regressions (e.g., Iversen and Cusack 2000). Finally, democracy potentially is a relevant moderator variable, as more democratic political systems may be generous government spenders, especially on social security and welfare. One explanation for that relation could be that the median voter prefers redistributive policies, providing incentives for governments to cater to those preferences (e.g., Meltzer and Richard 1981).

\footnotetext{
8 The information on the variables "Primary"and "CrossAuthor"can be collected from footnotes in the relevant studies.
} 


\subsection{Multivariate meta-regression results}

A few preliminary remarks are in order regarding the interpretation of the coefficients in the estimates of multivariate meta-regression models presented below. The models always omit one category (as the reference category) from each group of mutually exclusive and jointly exhaustive dummy variables (e.g., government spending or economic globalization measures). That is necessary to avoid perfect multicollinearity implying that the intercept $\beta_{0}$ cannot be interpreted as the "true" effect of globalization on government spending because it incorporates the effects of the reference groups. Other specifications would yield different estimates of the intercept term. Our specification provides an estimate of the impact of trade globalization on total government spending, based on data from advanced countries only-with all variables entered in their levels.

Note that the choice of the omitted (reference) categories in no way influences any of the other estimated coefficients, but it shifts the empirical model's intercept $\beta_{0} .{ }^{9}$ Hence, the coefficients of the moderator variables from each group of mutually exclusive and jointly exhaustive dummy variables allow us to make predictions regarding the impact of economic globalization on government spending based on the chosen reference categories. For example, the estimated average partial correlation of social spending compared to total government spending (which is the reference category) can be predicted by adding up the value of the intercept $\beta_{0}$ and of the social spending coefficient. Also be aware that we adopt a general-to-specific estimation approach, which is the suggestion of prominent guidelines for meta-analysis (e.g., Stanley and Doucouliagos 2012, p. 105). In particular, we eliminate the variable that returns the largest $p$ value when all coded moderators in Table 2 are entered and repeat that step until the $p$ values of all variables are smaller than $0.1 .{ }^{10}$ The advantage of the general-to-specific approach is "that model construction proceeds from a very general model in a more structured, ordered and (statistically valid) fashion, and in this way avoids the worst of data mining" (Charemza and Deadman 1997, p. 78).

Table 3 shows the general-to-specific modeling results from the multivariate metaregression analysis. ${ }^{11}$ Column (1) applies WLS with the standard errors clustered at the study level. The social spending variable returns a negative and statistically significant coefficient, indicating that-compared to estimates entering total government spending as the dependent variable (which is excluded as the reference category in the group of government spending measures) - estimates that model social spending alone report larger negative effects of globalization on total government spending. Indeed, our model predicts that globalization has a small-to-moderate negative impact on social spending of -0.1 (obtained by adding the social spending coefficient to the intercept). While the finding of a negative and statistically significant coefficient on the social spending variable in column (1) clearly contradicts the extended version of the 'compensation' hypothesis, which predicts that globalization has a differential impact on various components of government

\footnotetext{
${ }^{9}$ See Gechert and Rannenberg (2018, p. 1168).

${ }^{10}$ Note that we do not exclude dummy variables from groups of variables (i.e., "Government spending measures", "Economic globalization measures" and "Country composition") even if they are statistically insignificant. The reason is that by excluding variables from those groups, the interpretation of the respective coefficients relative to the omitted reference category would not work properly anymore.

${ }^{11}$ Regression results based on entering all the coded moderator variables are available upon request.
} 
spending and, in particular, will push up spending on social protection to compensate for the greater risks associated with international market integration (e.g., Rodrik 1998), it lends support to the extended version of the 'efficiency' hypothesis, which predicts the opposite, namely that social spending will be under more pressure from globalization than other components of public expenditures (e.g., Schulze und Ursprung 1999; see also Sect. 2.2). Notably, however, the size of the impact of globalization on social spending predicted by the model estimated in column (1) is small-to-moderate when its interpretation is based on the guidelines proposed by Doucouliagos (2011), which suggest that a partial correlation coefficient between zero and 0.07 must be considered to be small. In other words, the regression results do not predict a large negative impact of economic globalization on social spending, on average, but rather small-to-moderate downward pressure.

In fact, no government expenditure variable other than social spending carries statistical significance. The coefficients of the financial globalization and the overall economic globalization variables, however, are both positive and statistically significant. Those findings suggest that, compared to models that control for trade globalization, models that include financial globalization or overall economic globalization report larger (i.e., more positive) relationships between globalization and government spending. The meta-regression results suggest that the choice of the economic globalization variable indeed does matter and the 'compensation' effects reported in the literature tend to be stronger when the dimension of financial globalization is considered.

Furthermore, the results in column (1) of Table 3 indicate that, on average, estimates that rely on samples of developing countries find stronger relationships between economic globalization and government spending than those based on samples of advanced countries. That finding supports the argument that the composition of the country group moderates the impact of globalization on government spending in the sense that the 'compensation' mechanism, on average, is stronger in developing countries than in advanced countries. Note again, however, that the average 'compensation' effect in developing countries predicted by the model estimation in column (1) is rather small. Based on our categorization of reference groups, the model predicts that globalization has a small positive impact on total government spending in developing countries $(-0.05+0.12=0.07)$.

Furthermore, the results in model (1) of Table 3 suggest that the choice of functional form influences the reported partial correlations. The omitted reference category is the level level specification, i.e., when the spending and globalization variables both are entered in levels. It can be seen that estimates using functional forms other than level level report larger negative relations between globalization and government spending. Garrett (2001, p. 21) argues in favor of "an important analytic difference between the extent to which a given country is integrated into international markets in a given period of time (i.e., the level of integration) and the rate at which integration has increased between two periods (i.e., changes in market integration). The changes measure is much closer to conventional understandings of globalization, but the levels measure has been used in the best econometric work on the globalization and government spending relationship around the world."

Our meta-regression analysis shows that the evidence reported in the existing literature indeed leans meaningfully more towards supporting the 'compensation' hypothesis when both the government spending and the globalization variable are specified in levels. In particular, the model in column (1) of Table 3 predicts a medium-sized negative impact of globalization on total government spending $(-0.05+-0.11=-0.16)$ when the model is specified in first differences, which rejects the predictions of the 'compensation' theory clearly. 
Table 3 Multivariate regression results

\begin{tabular}{|c|c|c|c|c|c|}
\hline Dependent variable & $\begin{array}{l}\text { PartialCorr } \\
\text { (1) }\end{array}$ & $\begin{array}{l}\text { PartialCorr } \\
\text { (2) }\end{array}$ & $\begin{array}{l}\text { PartialCorr } \\
\text { (3) }\end{array}$ & $\begin{array}{l}\text { Fisher's z } \\
\text { (4) }\end{array}$ & $(5)$ \\
\hline Estimator & WLS & Random Effects & Robust regression & WLS & $\begin{array}{l}\text { Robust, sta- } \\
\text { tistically } \\
\text { signifi- } \\
\text { cant }\end{array}$ \\
\hline Constant & $\begin{array}{l}-0.046 \\
(0.040)\end{array}$ & $\begin{array}{l}-0.018 \\
(0.050)\end{array}$ & $\begin{array}{l}0.032 \\
(0.058)\end{array}$ & $\begin{array}{l}-0.048 \\
(0.043)\end{array}$ & No \\
\hline Standard error & $\begin{array}{l}0.604 * * \\
(0.278)\end{array}$ & $\begin{array}{l}0.613 * * \\
(0.272)\end{array}$ & $\begin{array}{l}0.510^{*} \\
(0.267)\end{array}$ & $\begin{array}{l}0.710 * * \\
(0.312)\end{array}$ & Yes \\
\hline \multicolumn{6}{|c|}{ Government spending measures } \\
\hline Social spending & $\begin{array}{l}-0.051^{* *} \\
(0.021)\end{array}$ & $\begin{array}{l}-0.068 * * * \\
(0.024)\end{array}$ & $\begin{array}{l}-0.081 * * \\
(0.032)\end{array}$ & $\begin{array}{l}-0.058 * * * \\
(0.022)\end{array}$ & Yes \\
\hline Public investment & $\begin{array}{l}0.159 \\
(0.107)\end{array}$ & $\begin{array}{l}0.096 \\
(0.117)\end{array}$ & $\begin{array}{l}0.029 \\
(0.087)\end{array}$ & $\begin{array}{l}0.242 \\
(0.191)\end{array}$ & No \\
\hline Government consumption & $\begin{array}{l}-0.013 \\
(0.025)\end{array}$ & $\begin{array}{l}-0.027 \\
(0.025)\end{array}$ & $\begin{array}{l}-0.043 \\
(0.033)\end{array}$ & $\begin{array}{l}-0.018 \\
(0.027)\end{array}$ & No \\
\hline Education spending & $\begin{array}{l}-0.039 \\
(0.027)\end{array}$ & $\begin{array}{l}-0.040 \\
(0.027)\end{array}$ & $\begin{array}{l}-0.048 \\
(0.030)\end{array}$ & $\begin{array}{l}-0.046 \\
(0.029)\end{array}$ & No \\
\hline Health spending & $\begin{array}{l}-0.021 \\
(0.022)\end{array}$ & $\begin{array}{l}-0.029 \\
(0.026)\end{array}$ & $\begin{array}{l}-0.041 \\
(0.029)\end{array}$ & $\begin{array}{l}-0.026 \\
(0.024)\end{array}$ & No \\
\hline Other spending & $\begin{array}{l}-0.010 \\
(0.022)\end{array}$ & $\begin{array}{l}-0.021 \\
(0.023)\end{array}$ & $\begin{array}{l}-0.028 \\
(0.026)\end{array}$ & $\begin{array}{l}-0.012 \\
(0.023)\end{array}$ & No \\
\hline \multicolumn{6}{|c|}{ Economic globalization measures } \\
\hline Financial globalization & $\begin{array}{l}0.041 * * * \\
(0.013)\end{array}$ & $\begin{array}{l}0.050 * * * \\
(0.016)\end{array}$ & $\begin{array}{l}0.058 * * * \\
(0.015)\end{array}$ & $\begin{array}{l}0.041 * * * \\
(0.014)\end{array}$ & Yes \\
\hline $\begin{array}{l}\text { Overall economic glo- } \\
\text { balization }\end{array}$ & $\begin{array}{l}0.054 * * * \\
(0.022)\end{array}$ & $\begin{array}{l}0.057 * * \\
(0.027)\end{array}$ & $\begin{array}{l}0.060 \\
(0.039)\end{array}$ & $\begin{array}{l}0.057 * * \\
(0.023)\end{array}$ & No \\
\hline \multicolumn{6}{|l|}{ Country composition } \\
\hline $\begin{array}{l}\text { Developing countries } \\
\text { only }\end{array}$ & $\begin{array}{l}0.121 * * * \\
(0.039)\end{array}$ & $\begin{array}{l}0.124 * * * \\
(0.033)\end{array}$ & $\begin{array}{l}0.126 * * * \\
(0.040)\end{array}$ & $\begin{array}{l}0.134 * * * \\
(0.044)\end{array}$ & Yes \\
\hline Mix of countries & $\begin{array}{l}0.024 \\
(0.019)\end{array}$ & $\begin{array}{l}0.020 \\
(0.021)\end{array}$ & $\begin{array}{l}0.026 \\
(0.026)\end{array}$ & $\begin{array}{l}0.021 \\
(0.020)\end{array}$ & No \\
\hline \multicolumn{6}{|l|}{ Econometric details } \\
\hline Change change & $\begin{array}{l}-0.109 * * * \\
(0.022)\end{array}$ & $\begin{array}{l}-0.116^{* * *} \\
(0.025)\end{array}$ & $\begin{array}{l}-0.113^{* * *} \\
(0.028)\end{array}$ & $\begin{array}{l}-0.117 * * * \\
(0.024)\end{array}$ & Yes \\
\hline Level change & $\begin{array}{l}-0.115^{* * * *} \\
(0.034)\end{array}$ & $\begin{array}{l}-0.125^{* *} \\
(0.051)\end{array}$ & $\begin{array}{l}-0.142 * * \\
(0.068)\end{array}$ & $\begin{array}{l}-0.125^{* * * *} \\
(0.037)\end{array}$ & Yes \\
\hline Change level & $\begin{array}{l}-0.101^{* * * *} \\
(0.019)\end{array}$ & $\begin{array}{l}-0.113^{* * * *} \\
(0.023)\end{array}$ & $\begin{array}{l}-0.123^{* * *} \\
(0.029)\end{array}$ & $\begin{array}{l}-0.108^{* * * *} \\
(0.021)\end{array}$ & Yes \\
\hline OLS & $\begin{array}{l}0.081 * * \\
(0.035)\end{array}$ & $\begin{array}{l}0.073 * * * \\
(0.036)\end{array}$ & $\begin{array}{l}0.053 * * \\
(0.026)\end{array}$ & $\begin{array}{l}0.088 * * \\
(0.039)\end{array}$ & Yes \\
\hline Random effects & $\begin{array}{l}0.069 \\
(0.070)\end{array}$ & $\begin{array}{l}0.062 \\
(0.060))\end{array}$ & $\begin{array}{l}0.046 \\
(0.043)\end{array}$ & $\begin{array}{l}0.075 \\
(0.077)\end{array}$ & No \\
\hline
\end{tabular}


Table 3 (continued)

\begin{tabular}{llllll}
\hline Dependent variable & PartialCorr & PartialCorr & PartialCorr & Fisher's z & \\
& $(1)$ & $(2)$ & $(3)$ & $(4)$ & $(5)$ \\
\hline Other estimator & -0.011 & -0.018 & -0.045 & -0.011 & No \\
& $(0.030)$ & $(0.033)$ & $(0.037)$ & $(0.032)$ & \\
Country fixed effects & $-0.054^{* * *}$ & $-0.064 * * *$ & $-0.083 * * *$ & $-0.058^{* * *}$ & Yes \\
& $(0.020)$ & $(0.018)$ & $(0.024)$ & $(0.020)$ &
\end{tabular}

Publication characteristics as well as macroeconomic, political and institutional control variables

\begin{tabular}{|c|c|c|c|c|c|}
\hline \multirow[t]{2}{*}{ Economics journal } & $0.070 * * *$ & $0.068 * * *$ & $0.061 * *$ & $0.075 * * *$ & Yes \\
\hline & $(0.020)$ & $(0.020)$ & $(0.026)$ & $(0.022)$ & \\
\hline \multirow[t]{2}{*}{ Prior } & $-0.040^{* * *}$ & $-0.044 * * *$ & $-0.047 * *$ & $-0.044 * * *$ & Yes \\
\hline & $(0.013)$ & $(0.015)$ & $(0.020)$ & $(0.013)$ & \\
\hline \multirow[t]{2}{*}{ GDP growth } & $-0.039 * * *$ & $-0.049 * *$ & $-0.054 * *$ & $-0.042 * * *$ & Yes \\
\hline & $(0.014)$ & $(0.019)$ & $(0.027)$ & $(0.015)$ & \\
\hline \multirow[t]{2}{*}{ Unemployment } & $0.040 * *$ & $0.048 * * *$ & $0.050 * *$ & $0.042 * *$ & Yes \\
\hline & $(0.016)$ & $(0.018)$ & $(0.023)$ & $(0.017)$ & \\
\hline \multirow[t]{2}{*}{ Terms of trade risk } & $-0.125^{* * *}$ & $-0.125^{* * *}$ & $-0.129 * * *$ & $-0.132 * * *$ & Yes \\
\hline & $(0.020)$ & $(0.038)$ & $(0.045)$ & $(0.020)$ & \\
\hline \multirow[t]{2}{*}{ Democracy } & $-0.047 *$ & $-0.048^{*}$ & -0.044 & $-0.054 * *$ & No \\
\hline & $(0.025)$ & $(0.026)$ & $(0.038)$ & $(0.027)$ & \\
\hline Observations & 1,182 & 1,182 & 1,182 & 1,182 & \\
\hline R squared (adjusted) & 0.258 & 0.357 & 0.267 & 0.253 & \\
\hline
\end{tabular}

Standard errors (in parentheses) are clustered at the study level. PartialCorr... Partial correlation. Fisher's Z... transformation of the partial correlations (e.g., Dunn and Clark 1969)

$*$, **, *** denote statistical significance at the $10 \%, 5 \%$ and $1 \%$ level, respectively. Details on the variables included are available in Table 2

Several additional findings from column (1) of Table 3 merit highlighting. First, estimates based on OLS estimators lean more towards supporting the 'compensation' hypothesis than other econometric specifications. In contrast, the estimated coefficients for Random Effects and other estimators (e.g., IV, seemingly unrelated regressions) are statistically insignificant. Second, entering country fixed effects moderates the impact of globalization on spending: if country dummies are included, the reported partial correlation tends to lean more towards the side of zero. Third, we find that estimates published in economics journals report stronger (i.e., more positive) relationships between globalization and government spending. In other words, the economics literature reveals a tendency for reporting positive globalization-spending effects. Fourth, scholars who have contributed to the relevant literature previously report partial correlations that tend to be more negative. Fifth, three regressors seem to moderate the impact of globalization on government spending. On the one hand, the two macroeconomic controls (GDP growth and unemployment) return statistically significant coefficients, suggesting that empirical researchers wanting to model the relationship between globalization and government spending should pay particular attention to macroeconomic controls. On the other hand, estimates based on models in which terms-of-trade risk also is controlled for report larger negative effects of 
globalization on government spending. The coefficients on democracy are significant in three of the four models reported in Table 3. Finally, we can ask whether the evidence for publication selection bias reported in Table 1 is confirmed when we control for additional moderator variables. Indeed, the standard error coefficients in Table 3 have the same signs as the coefficients reported in Table 1; the size of those coefficients is similar. That finding can be interpreted in the sense that the multivariate meta-regression analysis confirms that some publication selectivity bias exists in the globalization-spending literature, but the magnitude of the bias is relatively small (Doucouliagos and Stanley 2013, p. 320). Finally, our meta-regression results do not find substantial evidence for time-varying effects in the globalization-spending relationship: the general-to-specific approach eliminates the continuous variable capturing the mean year of the data's underlying structure because the coefficient on that variable is estimated to have very low precision. ${ }^{12}$

In columns (2)-(4) of Table 3, we test the robustness of the meta-regression results reported in column (1). We do so both by applying different estimators and by transforming the dependent variable. More specifically, the Random Effects model in column (2) introduces an additional between-study variance term to account for differences in the globalization-spending estimates that go beyond sampling error and differences captured by the moderator variables (e.g., Schmidt and Hunter 2014). The robust regression estimator applied in column (3) downweighs observations with larger absolute residuals and, hence, is less fragile to the influence of outlier observations. Finally, column (4) uses Fisher's $z$-transformed partial correlation coefficients to account for the distribution of the partial correlations potentially not being normal when their values are close to -1 and +1 . The results reported in columns (2)-(4) show that our baseline results largely remain unaffected when those robustness checks are introduced. The sizes of some of the coefficients and their standard errors are subject to variation. However, two cases arise in which a variable whose coefficient was estimated to be significant in column (1) turns out not to be significant in all three additional models: the coefficients on both overall economic globalization and democracy lose their significance when we apply robust regression methods. Besides that, the results in columns (2)-(4) of Table 3 indicate robustness.

\section{Conclusions}

By applying meta-analysis and meta-regression methods, this article has analyzed the literature addressing the impact of economic globalization on government spending. Based on statistically independent estimations (e.g., Rodrik 1998; Busemeyer 2009), some exercises in econometric replication (e.g., Kittel and Winner 2005) and qualitative reviews of the evidence (e.g., Brady et al. 2005), the previous literature has been unable to resolve conflicting theoretical arguments about whether the effect of globalization on public spending is either negative, positive, or much smaller than suggested by the two prominent rival theories (the 'efficiency' vs. 'compensation' hypotheses). Furthermore, the question whether different components of government spending are affected to different extents has so far not been answered rigorously. The present article contributes to the literature by providing

\footnotetext{
12 The appendix reports a robustness check concerning the finding that the time dimension does not seem to significantly contribute to explaining heterogeneity in existing globalization-spending estimates.
} 
the first quantitative analysis of the accumulated evidence and by exploring the possible sources of the wide variation in existing empirical estimates.

The meta-analysis presented herein suggests several main findings. First, the overall empirical evidence is inconsistent with strong unidirectional effects of globalization on government spending. Indeed, once we account for the (small magnitude of) publication selection bias in favor of the 'compensation' effects of economic globalization on government spending, no evidence is found of a non-zero average effect. That finding rejects both the simple version of the 'efficiency' hypothesis, which predicts sizeable negative effects of globalization on government spending as well as the simple version of the 'compensation' hypothesis, which predicts the opposite result.

Second, looking at different components of government spending is essential for testing the extended version of those two competing hypotheses, as both of them place special emphasis on the role of spending on social protection and welfare (e.g., Rodrik 1998; Schulze and Ursprung 1999). In that context, we find evidence rejecting the 'compensation' hypothesis in favor of the 'efficiency' hypothesis: our preferred meta-regression model predicts that globalization has a small-to-moderate negative impact on social spending. While our regression results clearly do not predict a large negative average impact, we find evidence that is consistent with the view that economic globalization exerts small-tomoderate downward pressure on social spending.

Third, while we find that the effect of interest depends on how government spending is measured (not all types of government spending are affected to the same extent by globalization), the meta-regression results also indicate that the choice of the economic globalization variable is relevant: the effects reported in the literature tend to lean more towards the 'compensation' hypothesis when the dimension of financial globalization is considered (rather than trade globalization only). Fourth, the meta-regression evidence suggests that the composition of the country group moderates the impact of globalization on government spending: developing countries, on average, have leaned more towards compensating citizens for the risks associated with economic globalization. Finally, our results indicate that at least some of the variation in the published globalization-spending results is the product of measurement and specification differences. What is most important, we confirm previous suspicions that the functional form of the empirical model's specification makes a significant difference and, hence, should be given prominent attention when it comes to interpreting the estimates of the globalization-spending relationship (Garrett 2001; Kittel and Winner 2005): the effect of globalization on government spending tends to be negative when we look at changes in market integration only (with the strongest negative effect being on social spending), but positive when both the globalization and government spending variables are entered in their levels.

Where do the results from the meta-analysis point in terms of defining a future research agenda on the globalization-spending relationship? First, researchers who provide statistically independent estimations could pay attention to the variables that we find to be significant moderators of the impact of economic globalization on government spending. Second, in future research it might be interesting to uncover the mechanisms that underlie our finding of an average globalization effect that is statistically indistinguishable from zero. Not all governments behave in the same way, and additional analyses that study specific countries could shed more light on why certain governments tend to compensate more vigorously for the greater employment and income risks associated with globalization by increasing spending (e.g., Steinmo 2002; Wu and 
Lin 2012; Saenz et al. 2013), while other governments cut certain types of spending and, thereby, help verify the 'efficiency' hypothesis. In particular, a substantial literature has argued that each nation's own history in terms of institutions and culture, the structures of the welfare state and of the political system (e.g., Navarro et al. 2004; Kim and Zurlo 2009) are important for understanding changes in government spending. Additional research could shed light on how specific national histories help explain the meta-study finding of a zero average impact of economic globalization on government spending. Third, future research could aim at developing meta-analyses exploring the effects of other institutional variables (e.g., partisan politics) on various components of government spending. Fourth, it might be fruitful to take onboard the recent influential debate about globalization and the emergence of populism (e.g., Rodrik 2018). Does globalization fuel populism and populism in turn drives (changes in) government spending? That aspect of ideology currently is missing from the econometric literature reviewed for our meta-analysis, and it might be interesting to study it in the context of how globalization may lead to "partisan political business cycles" (Belke 2000). Finally, various theories in the social sciences literature suggest that globalization may affect all sorts of other policy-relevant phenomena directly, including economic growth, income inequality, the tax structure and so on. Extensions of and adaptions to the meta-study approach proposed in this paper arguably are useful for addressing many other research questions on globalization's effects.

Acknowledgements Open access funding provided by Johannes Kepler University Linz. Financial support by the Chamber of Labor Vienna for a project titled "Fiscal policy in European context" is gratefully acknowledged. The author thanks Mario Holzner, Robert Stehrer, Stefan Jestl and three anonymous referees for very helpful comments on earlier drafts of this paper. All remaining errors are mine.

Open Access This article is licensed under a Creative Commons Attribution 4.0 International License, which permits use, sharing, adaptation, distribution and reproduction in any medium or format, as long as you give appropriate credit to the original author(s) and the source, provide a link to the Creative Commons licence, and indicate if changes were made. The images or other third party material in this article are included in the article's Creative Commons licence, unless indicated otherwise in a credit line to the material. If material is not included in the article's Creative Commons licence and your intended use is not permitted by statutory regulation or exceeds the permitted use, you will need to obtain permission directly from the copyright holder. To view a copy of this licence, visit http://creativecommons.org/licenses/by/4.0/.

\section{References}

Adam, A., \& Kammas, P. (2007). Tax policies in a globalized world: Is it politics after all? Public Choice, $133(3-4), 321-341$.

Adam, A., Kammas, P., \& Lagou, A. (2013). The effect of globalization on capital taxation: What have we learned after 20 years of empirical studies? Journal of Macroeconomics, 35(1), 199-209.

Alesina, A., \& Perotti, R. (1997). The welfare state and competitiveness. American Economic Review, 87(5), 921-939.

Andrews, A., \& Kasy, M. (2019). Identification of and correction for publication bias. American Economic Review, 109(8), 2766-2794.

Belke, A. (2000). Partisan political business cycles in the German labour market? Empirical tests in the light of the Lucas-Critique. Public Choice, 104(3-4), 225-283.

Brady, D., Beckfield, J., \& Seeleib-Kaiser, M. (2005). Economic globalization and the welfare state in affluent democracies, 1975-2001. American Sociological Review, 70(6), 921-948.

Bretschger, L., \& Hettich, F. (2002). Globalisation, capital mobility and tax competition: Theory and evidence for OECD countries. European Journal of Political Economy, 18(4), 695-716. 
Brodeur, A., Le, M., Sangnier, M., \& Zylberberg, Y. (2016). Star wars: The empirics strike back. American Economic Journal Applied Economics, 8(1), 1-32.

Busemeyer, M. (2009). From myth to reality: Globalisation and public spending in OECD countries revisited. European Journal of Political Research, 48(4), 455-482.

Cameron, D. (1978). The expansion of the public economy: A comparative analysis. American Political Science Review, 72(4), 1243-1261.

Charemza, W., \& Deadman, D. (1997). New directions in econometric practice. Cheltenham: Edward Elgar Publishing.

Chuaire, M., Scartascini, C., \& Tommasi, M. (2017). State capacity and the quality of policies: Revisiting the relationship between openness and government size. Economics and Politics, 29(2), 133-156.

Clark, W. (2000). Environmental globalization. In J. Nye \& J. Donahue (Eds.), Governance in a globalizing world (pp. 86-108). Washington, D.C.: Brookings Institution Press.

Cooper, H., \& Hedges, L. (1994). The handbook of research synthesis. New York: Russell Sage Foundation.

Cusack, T. (1997). Partisan politics and public finance: Changes in public spending in the industrialized democracies, 1955-1989. Public Choice, 91(3-4), 375-395.

DeLong, B., \& Lang, K. (1992). Are all economic hypotheses false? Journal of Political Economy, 100(6), 1257-1272.

Doucouliagos, H. (2011). How large is large? Preliminary and relative guidelines for interpreting partial correlations in economics. Deakin University Working Paper SWP 2011/5.

Doucouliagos, C., \& Stanley, D. (2013). Are all economic facts greatly exaggerated? Theory competition and selectivity. Journal of Economic Surveys, 27(2), 316-339.

Dreher, A. (2006). The influence of globalization on taxes and social policy: An empirical analysis for OECD countries. European Journal of Political Economy, 22(1), 179-201.

Dreher, A., Gaston, N., \& Martens, P. (2008a). Measuring Globalisation. Gauging Its Consequences. New York: Springer.

Dreher, A., Sturm, J., \& Ursprung, H. (2008b). The impact of globalization on the composition of government expenditures: Evidence from panel data. Public Choice, 134(3-4), 263-292.

Dunn, O., \& Clark, V. (1969). Correlation coefficients measured on the same individuals. Journal of the American Statistical Association, 64(325), 366-377.

Egger, M., Smith, G., Scheider, M., \& Minder, C. (1997). Bias in meta-analysis detected by a simple, graphical test. British Medical Journal, 315(7109), 629-634.

Epifani, P., \& Gancia, G. (2009). Openness, government size and the terms of trade. Review of Economic Studies, 76(2), 629-668.

Garrett, G. (1995). Capital mobility, trade, and the domestic politics of economic policy. International Organization, 49(4), 657-687.

Garrett, G. (1998a). Global markets and national politics: Collision course or virtuous Circle? International Organization, 52(4), 787-824.

Garrett, G. (1998b). Partisan politics in the global economy. Cambridge, MA: Cambridge University Press.

Garrett, G. (2001). Globalization and government spending around the world. Studies in Comparative International Development, 35(4), 3-29.

Gechert, S., \& Rannenberg, A. (2018). Which fiscal multipliers are regime-dependent? A meta-regression analysis. Journal of Economic Surveys, 32(4), 1160-1182.

Gräbner, C., Heimberger, P., Kapeller, J., \& Springholz, F. (2018). Measuring economic openness: A review of existing measures and empirical practices. ICAE Working Paper No. 86.

Gygli, S., Haelg, F., \& Sturm, J. (2019). The KOF globalisation index-revisited. Review of International Organizations, 14(3), 543-574.

Ha, E. (2008). Globalization, veto Players, and welfare spending. Comparative Political Studies, 41(6), $783-813$.

IMF. (2018). Challenges to steady growth, IMF World Economic Outlook October 2018. Washington, D.C.: International Monetary Fund.

Iversen, T., \& Cusack, T. (2000). The causes of welfare state expansion: Deindustrialization or globalization? World Politics, 52(3), 313-349.

Kim, T., \& Zurlo, K. (2009). How does economic globalization affect the welfare state? Focusing on the mediating effect of welfare regimes. International Journal of Social Welfare, 18(2), 130-141. 
Kittel, B., \& Obinger, H. (2003). Political parties, institutions, and the dynamics of social expenditure in times of austerity. Journal of European Public Policy, 10(1), 20-45.

Kittel, B., \& Winner, H. (2005). How reliable is pooled analysis in political economy? The globalization-welfare state nexus revisited. European Journal of Political Research, 44(2), 269-293.

Kwon, H., \& Pontusson, J. (2010). Globalization, labour power and partisan politics revisited. SocioEconomic Review, 8(2), 251-281.

Leibrecht, M., Klien, M., \& Onaran, O. (2011). Globalization, welfare regimes and social protection expenditures in Western and Eastern European countries. Public Choice, 148(3-4), 569-594.

Marshall, J., \& Fisher, S. (2015). Compensation or constraint? How different compositions of economic globalization affect government spending and electoral turnout. British Journal of Political Science, 45(2), 353-389.

Meltzer, A., \& Richard, S. (1981). A rational theory of the size of government. Journal of Political Economy, 89(5), 914-927.

Milner, H., \& Keohane, R. (1996). Internationalization and domestic politics: An introduction. In H. Keohane \& H. Milner (Eds.), Internationalization and domestic politics (pp. 3-24). Cambridge, MA: Cambridge University Press.

Navarro, V., Schmitt, J., \& Astudillo, J. (2004). Is globalization undermining the welfare state? Cambridge Journal of Economics, 28(1), 133-152.

Potrafke, N. (2009). Did globalization restrict partisan politics? An empirical evaluation of social expenditures in a panel of OECD countries. Public Choice, 140(1-2), 105-124.

Potrafke, N. (2015). The evidence on globalisation. The World Economy, 38(3), 509-552.

Razin, A., Sadka, E., \& Swagel, P. (2002). The aging population and the size of the welfare state. Journal of Political Economy, 110(4), 900-918.

Rodden, J. (2003). Reviving leviathan: Fiscal federalism and the growth of government. International Organization, 57(4), 695-729.

Rodrik, D. (1998). Why do more open economies have bigger governments? Journal of Political Economy, 106(5), 997-1032.

Rodrik, D. (2011). The globalization paradox: Democracy and the future of the world economy. New York: W.W. Norton.

Rodrik, D. (2018). Populism and the economics of globalization. Journal of International Business Policy, 1(1-2), 12-33.

Rudra, N. (2002). Globalization and the decline of the welfare state in less-developed countries. International Organization, 56(2), 411-445.

Saenz, E., Sabate, M., \& Gadea, D. (2013). Trade openness and public expenditure. The Spanish case, 1960-2000. Public Choice, 154(3-4), 173-195.

Scharpf, F., \& Schmidt, V. (2000). Welfare and work in the open economy. Oxford: Oxford University Press.

Schmidt, J., \& Hunter, F. (2014). Methods of meta-analysis: Correcting error and bias in research findings. Newbury Park: Sage Publications.

Scholte, J. (2008). Defining globalisation. The World Economy, 31(11), 1471-1502.

Schulze, G., \& Ursprung, H. (1999). Globalisation of the economy and the nation-state. The World Economy, 22(3), 295-352.

Shelton, C. (2008). The aging population and the size of the welfare state: Is there a puzzle? Journal of Public Economics, 92(3-4), 647-651.

Sinn, H. (1997). The selection principle and market failure in systems competition. Journal of Public Economics, 66(2), 247-274.

Squalli, J., \& Wilson, K. (2011). A new measure of trade openness. The World Economy, 34(10), $1745-1770$.

Stanley, T. (2001). Wheat from chaff: Meta-analysis as quantitative literature review. Journal of Economic Perspectives, 15(3), 131-150.

Stanley, T., \& Doucouliagos, H. (2012). Meta-regression analysis in economics and business. London: Routledge Advances in Research Methods.

Stanley, T., \& Doucouliagos, H. (2017). Neither fixed nor random: Weighted least squares meta-analysis. Statistics in Medicine, 34(13), 2116-2127.

Steinmo, S. (2002). Globalization and taxation: Challenges to the Swedish welfare state. Comparative Political Studies, 35, 839-862.

Stephens, J., Huber, E., \& Ray, L. (1999). The welfare state in hard times. In H. Kitschelt, P. Lange, G. Marks, \& J. Stephens (Eds.), Continuity and change in contemporary capitalism (pp. 164-193). Cambridge, MA: Cambridge University Press.

Streeck, W. (2014). Buying time. The delayed crisis of democratic capitalism. London: Verso Books. 
Sutton, A., Abrams, K., Jones, D., Sheldon, T., \& Song, F. (2000). Methods for meta-analysis in medical research. Chichester: Wiley.

Swank, D. (1998). Funding the welfare state: Globalization and the taxation of business in advanced market economies. Political Studies, 46(4), 671-692.

Wu, A., \& Lin, M. (2012). Determinants of government size: Evidence from China. Public Choice, 151(12), 255-270.

Publisher's Note Springer Nature remains neutral with regard to jurisdictional claims in published maps and institutional affiliations. 